\title{
Ekumenisiteit in dogmatologiese perspektief
}

C J Wethmar

\begin{abstract}
Ecumenicity in doctrinal perspective

In this article ecumenicity is studied from a doctrinal point of view. This requires a twofold approach: firstly an analysis of the relevant doctrine which in this case is that of the proprietates et notae ecclesiae and secondly a description of the ecumenical implications of the nature of church doctrine as such. This study indicates how the latter approach complements and enriches the former.
\end{abstract}

1

Inleiding

Met die ontspanning wat tans algemeen in menslike verhoudinge in Suid-Afrika moontlik word, is dit te voorsien dat ook kerklike verhoudinge 'n groter ontdooiing sal ervaar as wat die afgelope dekades moontlik was. Dit beteken dat 'n bloeitydperk in ekumeniese verhoudinge denkbaar is. Om optimaal van hierdie geleentheid gebruik te maak, sal egter fundamenteel besin moet word oor die eie aard van ekumeniese verhoudinge.

Hiermee is nie gesê dat daar nie reeds 'n oorweldigende hoeveelheid menings en publikasies oor die ekumeniese vraagstuk voorhande is nie. Die waarheid is dat die beskikbare literatuur in hierdie verband werklik onoorsigtelik geword het. Tog kan 'n mens nie sê dat alle probleme op ekumeniese gebied reeds bevredigend opgelos is nie. Heelwat misverstande, aksentverskille en oneffenhede bly nog steeds op hierdie terrein voortbestaan. Allesins rede dus vir voortgaande besinning.

Juis wanneer ekumeniese verhoudinge diepgaande beïnvloed word deur breër samelewingsprosesse bestaan die noodsaak daarvoor om die kerklike eie-aard van dergelike verhoudinge te bepaal. Net soos ekumenisiteit op kerklik onverantwoorde gronde uit die weg gegaan kan word, net so kan ekumeniese verhoudinge uit kerklik onaanvaarbare oorwegings nagestreef word. Dit gebeur, byvoorbeeld, wanneer kerklike verhoudinge aan die algemeen menslike motief van "eendrag maak mag" diensbaar gestel word. Sulke verhoudinge mag dan wel effektief wees, kerklik is dit nie meer nie.

Ten einde die ekumeniese dimensie en roeping van die kerk duidelik voor oë te $\mathrm{kry}$, word in hierdie artikel vanuit dogmatologiese perspektief daaraan aandag gegee. Die dogmatologiese perspektief waarvan hier ter sprake is, is tweevoudig van aard. Ten eerste hou dit in dat die ekumeniese roeping van die kerk inhoudelik in terme van die dogmatiese ekklesiologie ter sprake gebring word. Dit blyk dat veral die leer oor die eienskappe van die kerk in hierdie verband ter sake is. Maar algaande word ook duidelik dat dit nie net die inhoud van die kerklike leer en die sistematiese besinning daaroor in die dogmatiek is wat vir die verantwoording van die ekumenisiteit nuttig is nie. Ook 'n besinning oor die aard van die kerklike belydenis is daarvoor van belang. Dit is die tweede aspek van die dogmatologiese 
perspektief waaraan in hierdie artikel aandag gegee word. Ten spyte van die populêre vermoede dat "doctrine divides but service unites"1, blyk dit dat verskillende betekenisvolle perspektiewe in verband met die ekumeniese roeping van die kerk wat in die leer oor die eienskappe van die kerk na vore tree nog meer reliëf kry wanneer 'n mens daarna kyk in die lig van die konfessionele karakter van die kerk.

\section{Die eienskappe en kenmerke van die kerk}

Sowel in die formulering van ekumeniese beleid as in die dogmatologiese verantwoording daarvan speel die leer oor die eienskappe van die kerk 'n belangrike rol'2. In die Nuwe Testament self is daar nog nie sprake van eienskappe van die kerk nie. Weliswaar word dikwels na die lidmate van die kerk as "heiliges" verwys dog van die heiligheid van die kerk word slegs een maal melding gemaak te wete in Ef 5:27. Ten einde aan hierdie Skrifgedeelte reg te laat geskied, is dit belangrik om daarop te let dat die term "heilig" hier nie as 'n vanselfsprekende beskrywing gebruik word nie. Dit word gebruik as aanduiding van wat Christus in die kerk tot stand gebring het en wat dus as grondslag vir hulle lewe behoort te dien ${ }^{3}$.

Langsamerhand kom in die geskiedenis van die kerk meer uitsprake oor die eienskappe van die kerk voor. So, byvoorbeeld, beskryf Ignatius van Antiochië en Polikarpus van Smirna die kerk as "heilig" en "katoliek"4. Die eerste amptelike neerslag van die leer oor die eienskappe van die kerk tref ons aan in die Symbolum Nicaeno - Constantinopolitanum uit die jaar $381 \mathrm{n} \mathrm{C}$ waar dit voorkom in die

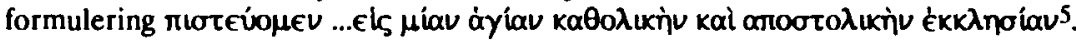
Sedertdien geld hierdie vier kwalifikasies, te wete eenheid, heiligheid, katolisiteit en apostolisiteit as die eienskappe van die kerk. Deur die eeue heen word telkens weer juis hierdie vier terme gebruik om die eiesoortigheid van die kerk aan te dui. Hierdie terminologiese volharding kan moeilik anders interpreteer word as 'n aanduiding van die geweldige rykdom aan perspektiewe wat in die hantering van hierdie omskrywings geleë is 6 .

By 'n besinning oor hierdie eienskappe en die implikasies wat dit vir die ekumeniese roeping van die kerk het, moet steeds in gedagte gehou word dat dit nie maar net om vier van mekaar geïsoleerde kwalifikasies gaan nie. Ons het hier te doen met vier dimensies van dieselfde werklikheid7. Dit beteken dat hulle met mekaar verband hou. Hulle beïnvloed mekaar oor en weer en is op 'n verskeidenheid van maniere van mekaar afhanklik ${ }^{8}$. En verder hou dit in dat wanneer een van hierdie eienskappe in die beskrywing van die kerk verwaarloos word ook die ander eienskappe nie tot hulle reg kom nie ${ }^{9}$. Van elkeen van hierdie eienskappe van die kerk geld dus dat hulle slegs in verhouding tot die ander drie tot hulle reg kom ${ }^{10}$.

Wat die funksionering van hierdie eienskappe betref, is dit belangrik om te beklemtoon dat hulle nie as outomatiese of vanselfsprekende konstateringe geld nie ${ }^{11}$. Net soos die kerk in die Gereformeerde tradisie as geloofsvoorwerp beskryf word, word ook die eienskappe van die kerk ten diepste as belydenisuitsprake ter sprake gebring. Hierdie eienskappe kan in die laaste instansie alleen in geloof aan die kerk toegeskryf word.

Juis omdat dit die geval is, word die eienskappe van die kerk sedert die Reformasietyd met die leer oor die kenmerke van die kerk in verband gebring 12 . 
Dit is belangrik om noukeurig tussen die kenmerke of notae ecclesiae enersyds en die eienskappe van die kerk andersyds te onderskei ${ }^{13}$. Die kenmerke dui op die voorwaardes of kriteria vir kerkwees terwyl die eienskappe die gevolge of wyse van kerkwees verteenwoordig.

As kenmerke van die kerk het die Reformatore reeds die suiwer prediking van die evangelie, die suiwer bediening van die sakramente en die uitoefening van die kerklike tug aangewys ${ }^{14}$. Die eintlike bedoeling by die aanwending van hierdie kenmerke is dat die kerk aan die lewende en werksame gesag van Christus onderworpe sal bly. Ten diepste is dit Christus self wat bepaal of die kerk werklik kerk is ${ }^{15}$. Konkreet word hierdie bepaling aan die hand van die Heilige Skrif gedoen.

Dat dit so gesien word, hang daarmee saam dat die kerk in die Reformatoriese tradisie steeds as kerk van die Woord geld. Daarom kon Luther reeds sê dat Gods volk nie sonder Gods Woord kan wees nie, maar ook omgekeerd dat Gods Woord ook nie sonder Gods volk kan wees nie ${ }^{16}$. Die bedoeling van die sakramente is om as verseëling van die Woord te dien. Daarom word daarvan soms as die sigbare Woord gepraat ${ }^{17}$. Die Woord van God roep in die kerk die belydenis na vore. ' $n$ Mens sou ook kon se dat die belydenis die wyse is waarop die gesag van die Skrif hom in die kerk laat geld. Die belydenis dui die ruimte aan waarin die Woord werksaam is in die gemeente. Wie tot die gemeente behoort en wil behoort, sal dus steeds binne hierdie grense beweeg. Die lidmaat self maar ook die gemeente maak erns daarmee dat hierdie belydenis gehandhaaf word. Dit is wat bedoel word met die stelling dat die kerklike tug die derde kenmerk van die ware kerk is.

Die leer oor die kenmerke van die kerk het ontwikkel in 'n situasie waar instansies wat verskil van mekaar tegelyk daarop aanspraak maak om die ware kerk te wees ${ }^{18}$. In hierdie leer gaan dit dus nie alleen om die waar van die kerk nie maar ook om die waarheid daarvan ${ }^{19}$. Aan die hand van die vermelde kenmerke kan onderskei word tusen dit wat ware kerk enersyds en valse kerk andersyds is.

Hiermee is egter nie gese dat dit die bedoeling van die notae ecclesiae is om kerklike eksklusiwisme te bevorder nie. Die oortuiging dat 'n mens tot die ware kerk behoort is nie dieselfde as om te meen dat jy tot die enigste ware kerk behoort nie. So 'n houding van engheid was nooit die bedoeling van die Gereformeerde belydenis nie 20 . 'n Mens kan jou daarom ook nie op hierdie belydenis beroep vir die gedagte dat dit ook 'n kenmerk van 'n ware kerk is dat so 'n kerk daarna moet streef om alle Christen-gelowiges in homself te vergader nie.

Die leer van die kenmerke van die kerk het 'n toetsende funksie. Dit wil verseker dat die kerk steeds is wat dit bely om te wees ${ }^{21}$. As sodanig verseker dit 'n eiesoortige dinamiek in die kerk ${ }^{22}$. Maar dan moet steeds bedink word dat die kritiese funksie van die kenmerke nie slegs na buite gerig mag word nie. Die toetsende werking daarvan behoort in eerste instansie na binne te beweeg. En dit dan ook nog op so 'n wyse dat die persoonlike faset daarvan nie agterweẽ gelaat word nie. Dat dit die geval is, blyk daaruit dat die Nederlandse Geloofsbelydenis die kenmerke van die ware kerk verbind met die kenmerke van die Christengelowiges $^{23}$ terwyl die Heidelbergse Kategismus die geloof aan die kerk verbind met die ootmoedige selfbewustheid "dat ek daarvan 'n lewende lid is en ewig sal bly"24. In die funksionering van die kenmerke van die ware kerk mag hierdie twee, die institusionele en die persoonlike nie van mekaar geskei word nie omdat dit dan onderskeidelik tot 'n onchristelike institusionalisme of 'n onbybelse individualisme sal lei25. Die toetsingselement en die daarmee gepaardgaande dinamiek wat steeds 
kenmerkend is van die Gereformeerde ekklesiologie dui daarop dat die kerk waaroor dit hier gaan nie op 'n ideaalbeeld van die kerk betrekking het nie maar op die konkrete kerk wat van sy swakhede bewus is ${ }^{26}$.

\section{Eenheid, heiligheid, katolisiteit en apostolisiteit}

3.1 Eenheid. Die eerste eienskap wat deur die Nicaeno - Constantinopolitanum genoem word, is die eenheid van die kerk. Hierdie eenheid het sy diepste oorsprong nie by die lidmate van die kerk nie maar by die drie-enige God wat die kerk in aansyn roep en in stand hou ${ }^{27}$. Die eenheid van die kerk hang dus saam daarmee dat alle Christene deur die geloof aan dieselfde God verbonde is. In die lig daarvan is dit begryplik dat God nie meer as een volk kan hê nie 28 net soos Christus nie meer as een liggaam ${ }^{29}$ en die Heilige Gees nie meer as een tempel kan hê nie ${ }^{30}$. Hierdie een kerk is een in geloof, getuienis en diens ${ }^{31}$.

Oor die feit dat die kerk één is, bestaan daar dus geen stryd nie. Wat egter wel omstredenheid veroorsaak, is die vraag hoe hierdie eenheid konkreet verwerklik moet word. In hierdie verband tref 'n mens in die huidige ekumeniese diskussie veral twee teenoorstaande standpunte aan. By gebrek aan beter terme sou dié posisies beskryf kon word as dié van die ekumeniese idealiste enersyds en dié van die ekumeniese realiste andersyds. Eersgenoemde lè sterk klem daarop dat alle gelowiges in Christus éćn is en dat hierdie feit impliseer dat daar 'n konkrete institusionele gestalte hiervoor gevind moet word ${ }^{32}$. Verteenwoordigers van hierdie standpunt meen dat hulle die Bybel volledig aan hulle kant het. Die gedagte dat die geloofseenheid tussen Christene 'n onsigbare eenheid sou wees, word fel bestry. In hierdie kring word wel gesê dat die institusionele eenheid wat hier in gedagte is geen eenvormigheid impliseer nie. Half in die verbygaan word gewoonlik daarvan gewag gemaak dat die beoogde institusionele eenheid hoegenaamd nie afdoen aan die reg tot eiesoortige, taalmatige, kulturele of denominasionele vormgewing van die geloof nie. Om kerkgrense egter met hierdie nasionale, kulturele of historiese geledinge te laat saamval sou onaanvaarbare natuurlike teologie wees.

Hierteenoor beklemtoon die ekumeniese "realiste" dat institusionele kerkeenheid oor kulturele en nasionale grense heen telkens voor skynbaar onoorkomelike probleme te staan kom. Hulle wil hierdie vraagstuk probeer oplos deur op grond van die vermelde kerkhistories duidelik vasstelbare probleme sonder meer tot die prinsipiële reg en noodsaak van 'n aan die kulturele, nasionale en historiese pluraliteit korresponderende pluriformiteit van kerke te konkludeer ${ }^{33}$.

Die diskussie tussen hierdie twee teenoorstaande posisies gaan nog steeds voort. In die Suid-Afrikaanse konteks word dit verder gekompliseer deurdat dit onafwendbaar besien word in die lig van die kulturele en etniese teenstellings wat kenmerkend is van die algemene samelewingsproblematiek.

3.2 Heiligheid. Die een kerk van Christus is ook heilig. Histories is die heiligheid van die kerk op verskillende maniere interpreteer. In die Oosterse kerk is dit opgevat in die sin dat die gemeente deel het aan die "heilige dinge", dit wil sê aan die gebeure en elemente van die sakramente. In die Latynse Weste is hierdie belydenis so uitgelê dat dit dui op die gegewe dat die gemeente in gemeenskap staan met die gelowiges wat reeds oorlede is ${ }^{34}$.

Die Reformasie het, sonder om die vermelde interpretasies geheel uit die 
ong te verloor, die heiligheid interpreteer in die sin van congregatio sanctorum. Met ander woorde, die gemeente is die vir God en deur God afgesonderdes ${ }^{35}$.

'n Vlugtige blik op die kerkgeskiedenis sal duidelik maak dat daar dikwels weinig van hierdie heiligheid tereggekom het. Daar moet egter steeds in gedagte gehou word dat die kerk nie as vergadering van heiliges bely word op grond van wat die lidmate in hulleself is nie. Wat hulle heilig maak is dit wat hulle ontvang: die Woord van God, ${ }^{36}$ die doop, die nagmaal, die Heilige Gees en die heilsweldade van Christus $^{37}$. Waar die kerk uit hierdie geskenkte heiligheid lewe, is hy geroep om self ook heilig te lewe. Ook in hierdie opsig is die kerk geroep om te wees wat hy in Christus is. En dit geld van sowel die individuele lidmate as van die kerk in die geheel.

3.3 Katolisiteit. Die term "katoliek" kom nie in die Nuwe Testament self voor nie. Soos eerder reeds vermeld, word dit vir die eerste keer aangetref in Ignatius se brief aan die gemeente te Smirna ${ }^{38}$. In hierdie brief maak Ignatius van die "katolieke kerk" in Christologiese konteks gewag as hy onder andere tot die uitspraak kom"...waar Jesus Christus is, daar is ook die katolieke kerk"39. In lyn met hierdie formulering het die Reformatore die term "katoliek" graag met "Christelik" vertaal, soos blyk uit die wyse waarop die Heidelbergse Kategismus die negende artikel van die Apostolicum interpreteer.

Soos bekend dui die term "katoliek" op geheelheid en omvattendheid. Hierdie omvattendheid kan betrekking hê op tyd, ruimte, kultuur en waarheid40.

Wanneer van die katolisiteit van die kerk in tydskategorieë gepraat word, word bedoel dat die kerk 'n tydsomvattende werklikheid is. In hierdie sin bely die Nederlandse Geloofsbelydenis in artikel 29 dat die kerk van die begin van die wêreld af daar was en dat dit tot die einde daar sal wees. Hierdie soort katolisiteit kan ook historiese katolisiteit genoem word.

Die gebruik van die term "katoliek" in ruimtelike terme daarenteen, dui daarop dat die kerk nie alleen die ganse wêreldtyd heslaan nie maar onk die hele wêreldruimte. Die kerk is oor die hele wêreld versprei en verstrooi sê die Nederlandse Geloofsbelydenis in die pas vermelde artikel ook. In hierdie geval gaan dit dus om 'n geografiese katolisiteit.

Met laasgenoemde hang ook die kulturele katolisiteit saam ${ }^{41}$. Die kerk word versamel uit die ganse menslike geslag ${ }^{42}$ want uit al die nasies moet dissipels gemaak word ${ }^{43}$.

In hierdie verband beklemtoon die Heidelbergse Kategismus egter dat die kerk wat so na vore tree dit doen in "die eenheid van die ware geloof"44. Daarmee is gese dat historiese, geografiese en kulturele omvang op sigself nog nie die kerk katoliek maak nie ${ }^{45}$. Hierdie drie fasette van die katolisiteit word dikwels die kwantitatiewe katolisiteit genoem. Hiervan word die kwalitatiewe katolisiteit onderskei wat dui op die volle diepte en omvang van die evangelieboodskap en die volheid van die heil waarvan dit getuig en waaraan die gelowige in Christus en deur die Heilige Gees deel kry. Die kwantitatiewe katolisiteit is pas moontlik as dit in die kwalitatiewe katolisiteit gegrond is. Dit is belangrik om te beklemtoon dat die katolisiteit nie 'n vanselfsprekende werklikheid is nie. Slegs deur 'n lewende en volhardende verbondenheid aan Christus en die Heilige Gees het die gemeente aan die katolieke volheid van die heil deel ${ }^{46}$.

Ook die kwantitatiewe faset van die katolisiteit is nie 'n vanselfsprekende 
voorhandenheid nie. Alleen in die geloof het die kerk daaraan deel. Tot die katolieke, dit wil se universele kerk behoort nie alleen al die kerke van 'n bepaalde tyd nie dog verder sowel al die kerke van die daaraan voorafgaande tye as dié wat in die toekoms tot aan die einde van die tyd nog sal $\mathrm{kom}^{47}$. Pas in die voleinding sal die katolisiteit van die kerk volledig verwerklik wees. In hierdie sin is die katolisiteit dus 'n eskatologiese begrip. Dat dit die geval is, beteken nie dat die katolisiteit vir die strydende kerk op weg na die voleinding geen realiteit is nie. Dit beteken wel dat die kerk op sy weg deur die geskiedenis heen slegs gedeeltelik as katoliek geken word 48 . Die universele kerk word telkens slegs in 'n bepaalde konkrete gestalte geken. In soverre so 'n partikuliere kerk egter die Skrif binne 'n bepaalde historiese konstellasie van verstaansvoorveronderstellinge suiwer vertolk en bereid is om van hierdie vertolking verantwoording af te lêt teenoor vertolkings wat vanuit ander verstaansvoorveronderstellinge gemaak is en gemaak word, verteenwoor dig so 'n partikuliere kerk die universele of katolieke kerk.

Dit sal egter duidelik wees dat geen partikuliere verskyningsvorm van die een katolieke kerk daarop aanspraak sal kan maak dat alle ander verskyningsvorme daarvan aan hom gelykvormig moet wees nie. Op weg na die voleinding kan die katolisiteit van die kerk daarin tot uitdrukking kom dat die verskillende partikuliere kerke die ander in hulle kerklike bestaan en praktyk respekteer en ernstig neem. Respekteer en ernstig neem, beteken nie noodwendig vereenselwiging nie. Dit is vir die kerk nie maar om't ewe wat hy bely nie. Daarom is dit moontlik dat 'n mens 'n bepaalde posisie kan respekteer terwyl jy self tog daarvan moet verskil ${ }^{\mathbf{4 9}}$.

3.4 Apostolisiteit. Die aandag is reeds eerder daarop gevestig dat die vier eienskappe van die kerk ten nouste met mekaar saamhang. Tog moet 'n mens sè dat in hierdie samehang die apostolisiteit 'n besondere plek inneem ${ }^{50}$. Met die apostolisiteit word naamlik bedoel dat die een, heilige en katolieke kerk gebaseer is op en gebonde is aan die oorspronklike apostoliese getuienis aangaande Jesus Christus $^{51}$. Die gebondenheid aan hierdie getuienis, beteken nie net maar die starre handhawing van oorgelewerde formules nie, maar dit dui op 'n lewe waarin 'n lewende verhouding met die verhoogde Christus verwerklik word en waarin die gelowige deel kry aan die sending van Christus in die wêreld 52 .

'n Mens sou kon sê dat die apostoliese getuienis die neerslag is van die oorspronklike teenwoordigheid van Christus in die wèreld. Die apostolisiteit van die kerk bestaan in die blywende, lewende en suiwer gelding van hierdie getuienis dwarsdeur die geskiedenis van die kerk. Oor die wyse waarop hierdie gelding voltrek word, is daar oor die eeue heen steeds gedebatteer. Teenoor die tradisioneel Rooms-Katolieke siening van die successio apostolorum word van Reformatoriese kant die successio doctrinae verdedig53. Die maatstaf aan die hand waarvan bepaal word wat ware eenheid, heiligheid en katolisiteit is, is die leer van die kerk. In die suiwer leer word die apostoliese oorsprong van die kerk blywend gehandhaaf. Met die beklemtoning van die successio doctrinae word die rol wat mense deur die loop van die geskiedenis heen gespeel het en steeds speel in die oordrag van die apostoliese getuienis nie ontken nie. Wat daarmee wel gesê word is dat hierdie menslike rol in diens geneem is en genormeer word deur die lewende gesag van die Woord van God.

Hier is dus van 'n dubbele normatiwiteit sprake ten opsigte waarvan die onderskeiding tussen norma normans en norma normata gebruiklik geword het. Die 
kerklike belydenis as norma normata moet steeds weer getoets word aan die Heilige Skrif as die norma normans.

Wanneer ons dit nou hier oor die apostolisiteit van die kerk het, moet steeds onthou word dat dit daarin nie om ' $\mathrm{n}$ vanselfsprekende konstatering aangaande die kerk gaan nie. In die Reformatoriese tradisie kom ook die apostolisiteit alleen ter sprake teen die agtergrond van die oortuiging ecclesia reformata semper reformanda. Hierdie formulering is nie bedoel as 'n oppervlakkige en maklik hanteerbare leuse wat sonder veel eksistensiële erns gemaak kan word nie ${ }^{54}$. Die Reformatoriese kerk weet dat hy van sy apostolisiteit alleen kan praat in die konteks van 'n blywende oproep om aan die Woord van God en die suiwer belydenis getrou te bly. En dit kan hy alleen doen as hy steeds bereid is om sy tekort in hierdie verband as skuld te bely en uit die vergewing daarvan te leef.

Konfessionaliteit en ekumene

Verskillende ekklesiologiese gesigspunte wat uit die voorafgaande beskrywing van die eienskappe van die kerk na vore getree het en wat vir die ekumenisiteit van belang kan wees, sou verder belig kon word wanneer 'n mens aandag gee aan die konfessionele karakter van die kerk en aan die rol wat die belydenis in die kerk speel. Hierdie benadering van die ekumenisiteitsproblematiek is voor die hand liggend omdat juis konfessionele probleme 'n fundamentele rol daarin speel.

Die belydenis is vir die kerk geen opsionele luukse nie. Die belydenis is die wyse waarop die kerk wat deur die Woord van God in aansyn geroep word, bestaan. Om van ' $n$ belydende kerk te praat, beteken om jou aan 'n toutologiese uitdrukking skuldig te maak 55 .

Die belydenis is ten nouste verbonde met dit wat die geloof self is. Opvallend is die feit dat die ondersoek van die Nuwe Testament aan die lig gebring het dat reeds in die Heilige Skrif self uitinge aangetref word wat beskou kan word as oorsprongsvorme van die latere kerklike belydenis 56 . In die besonder is die aandag gevestig op Rom 10:9 waar gesê word: "As jy met jou mond bely dat Jesus die Here is, en met jou hart glo dat God Hom uit die dood opgewek het, sal jy gered word". $\mathrm{Na}$ aanleiding van die woorde "bely" en "glo" wat hier gebruik word, is daar in die Nuwe Testamentiese belydenisse twee elemente geìdentifiseer wat onderskeidelik met die terme "homologie" en "credo" aangedui is ${ }^{57}$. Met die term "homologie" word gesê dat dit in die belydenis in die eerste instansie gaan om 'n eksistensiële daad waarin jy jouself aan Christus bind. Anders gesê: in die belydenis gaan dit om 'n omvattende lewensbeslissing waarin die mens homself resloos by Jesus skaar. Maar daar is ook nog ' $n$ tweede element in die belydenis aanwesig en dit is die beskrywing van die heilshistoriese werklikheid waarop die persoonlike beslissing en posisiekeuse gegrond is. Dit is hierdie element wat met die term "credo" aangewys word. Dit gaan in die belydenis dus om die geloof as daad en omvattende historiese gebeure enersyds en om die geloof as leerinhoud andersyds. 'n Noukeurige ondersoek van die Apostolicum toon aan dat beide hierdie twee struktuurelemente duidelik daarin werksaam is ${ }^{58}$.

Hierdie aanvanklike aanduiding van twee formele elemente in die struktuur van geloofsuitsprake is later verfyn toe daar vasgestel is dat in die wyse waarop die geloof in die Heilige Skrif ter sprake kom daar'n hele aantal grondvorme of struktuurelemente onderskei kan word. Naas belydenis as beslissing en leer is daar 
ook nog die elemente gebed, doksologie, getuienis en voorskrif aangedui 59 . Vir 'n geloofsantwoord om Bybels verantwoord te wees, moet dit nie alleen 'n suiwer weergawe van die inhoud van die Skrifboodskap wees nie, maar dit moet ook aan die formele vereistes wat aan die Bybelse voorbeeld ontleen kan word, voldoen.

Wat hier nou beklemtoon moet word is die gegewe dat die geloofsantwoord in sy geheel alleen dan die vorm het wat dit op grond van die Bybelse model behoort te hê, wanneer al die aangewese formele elemente daarin aanwesig is ${ }^{60}$. Wanneer een of meer van die vermelde grondvorme of struktuurelemente van geloofsuitsprake ten opsigte van die ander verabsoluteer word, het dit nie alleen formele nie maar ook inhoudelike konsekwensies en lei dit daartoe dat die oorspronklike Christelike boodskap in 'n onsuiwere perspektief te staan kom. Die ontstaan van 'n dergelike onsuiwere perspektief op die geloof is 'n konstante gevaar vir die kerk. 'n Vlugtige blik op die kerkgeskiedenis leer dat dit vroeg reeds voorgekom het. Veral twee struktuurelemente is ten opsigte van die ander verabsoluteer en dit is die leer-element enersyds en die voorskriftelikheids- of juridiese element andersyds.

Wanneer die leer-element verabsoluteer word, word die Christendom hoofsaaklik 'n intellektuele aangeleentheid. Die geloof is dan bloot 'n funksie van die menslike rede. Indien 'n mens nou sou aanneem dat die grondstruktuur van die menslike rede oral en altyd dieselfde bly, volg daaruit noodwendig dat kerkeenheid opgevat moet word as 'n strakke leereenvormigheid. So is reeds in die tweede eeu na Christus geredeneer in die Hellenistiese Logosteologie ${ }^{61 .}$

Nou is die opvallende dat ook die tweede vorm van verabsolutering wat sopas vermeld is, naamlik dié van die juridiese element tot presies dieselfde resultaat lei, naamlik die stelling dat die enigste aanvaarde vorm van kerkeenheid die is wat in 'n strenge leereenvormigheid tot uitdrukking kom. Hierdie verabsolutering het in die vroeë kerk tot stand gekom omdat die politieke owerheid in die Romeinse ryk nie kon toelaat dat die politieke eenheid deur geloofsdiversiteit in gevaar gestel word nie ${ }^{62}$. Daarom is daar van staatsweë aangedring op eenvormigheid in die belydenis. En hierdie belydenis word dan mettertyd ook deel van die wet van die staat. Dit bring nou egter mee dat die kerklike belydenis nie meer 'n gegewe is wat op grond van die getuieniskarakter daarvan deur inherente geestelike krag oproep tot deelname daaraan nie. Dit het 'n grootheid geword wat op grond van formele gesag aanvaar moes word. Die belydenis het 'n regsdekreet geword.

Hierdie verabsolutering van die juridiese moment in die belydenis word algaande in die geskiedenis ook vanuit kerklike kant voltrek wanneer in die voorreformatoriese teologie die opvatting ontstaan dat die Heilige Skrif 'n duister boek is ${ }^{63}$. Die heil word dan nie verkry in die geloof wat mede uit 'n verstaan van die Skrifboodskap tot stand kom nie. Volgens hierdie opvatting word dit eerder ontvang deur die sakramente van die kerk. Om so aan die heil deel te kry moet 'n mens aan die kerk behoort. En om aan die kerk te behoort, veronderstel gehoorsaamheid aan die voorskrifte van die kerklike leeramp. Langs hierdie weg word die belydenis versmal van 'n omvattende eksistensiële lewensuiting tot 'n daad van formele gehoorsaamheid. Ook op hierdie wyse ontwikkel die situasie dus dat die eenheid van die kerk tot uitdrukking kom in 'n streng juridies versekerde eenheid in die leer.

Aan hierdie verenging van die geloof tot onderskeidelik 'n abstrakte idee en 'n wet en aan die hieraan korresponderende gedagte van kerkeenheid as 'n strakke 
leer-eenvormigheid ontkom die Reformasie met sy herontdekking van die woordkarakter van die Heilige Skriff4. Nou word die geloof weer gesien as die bestaansomvattende hoor van Gods Woord en die kerk as creatura evangelii. Wanneer streng aan hierdie insig vasgehou word, kan in die Reformatoriese tradisie die geskiedenis van die kerk mettertyd beskryf word as die geskiedenis van die uitleg van die Heilige Skriffs. Ten einde telkens verstaan en geglo te word, moet die Skrif in verskillende tye en plekke verskillend vertolk word ${ }^{66}$. Die kerklike vertolking van die Woord geskied in die belydenis.

Die belydenis van die kerk is dus die wyse waarop die Woord van God op 'n bepaalde tyd en plek, dit wil sê, in 'n bepaalde konkrete situasie tot gelding kom. As sodanig funksioneer die belydenis in die eerste instansie binne 'n plaaslike kerk. En met plaaslike kerk word bedoel daar waar 'n sodanige stel van gemeenskaplike verstaans-voorveronderstellings bestaan dat van 'n gemeenskaplike verstaanshorison gepraat kan word - 'n gemeenskaplike verstaanshorison waarbinne die geloofsverbondenheid aan Christus 'n bepaalde identifiseerbare struktuur gaan vertoon 67 . Hierdie identifiseerbare struktuur vind neerslag in die belydenis. Die feit dat daar in die wyse waarop die Woord van God geskied so iets as 'n belydenis onderskei moet word, hang ten nouste saam met die historisiteit van die menslike bestaan en die daaraan korresponderende horisontaliteit van sy verstaan. Hiermee hang eweneens saam dat die belydenis steeds deur sowel voorlopigheid as finaliteit gekenmerk word. Die belydenis is finaal omdat daarin ' $n$ definitiewe verbondenheid aan Christus verwerklik word waarin die eskatologiese heil van God geskied. Maar dit is ook voorlopig omdat dit vanuit 'n historiese en steeds deur die sonde bepaalde situasie geskied. Dit staan steeds onder die begeleidende korreksie van die Heilige Skrif68.

Byna ongemerk kom hier 'n vraag na vore wat vir die behandeling van die tema "konfessionaliteit en ekumene" van besondere belang is en dit is die vraag na die verhouding tussen Skrif en belydenis. Dit is ' $n$ tema wat in die Gereformeerde teologie oor die jare heen intense aandag ontvang het al sou ' $n$ mens nie kon sê dat die betrokke verhouding altyd duidelik genoeg beskryf is nie. Die onduidelike lê daarin dat Skrif en belydenis in die proses dikwels aan mekaar gelykgestel word. Wel bestaan daar ' $n$ intütiewe aanvoeling dat dit verkeerd is om hierdie twee groothede met mekaar te identifiseer. Daarom word daar tussen hulle onderskei deur die verhouding tussen hulle te beskryf as dié van 'n norma normans en 'n norma normata. Maar tog word dan nog gesê dat wat inhoud betref daar 'n identiteit bestaan tussen Skrif en belydenis.

Maar met die stelling van 'n inhoudelike identiteit is daar 'n probleem geskep. Hoe kan 'n mens die inhoud van 'n uitspraak agterhaal sonder om van die vorm kennis te neem? Daarom is die vorm-inhoudskema nie geskik om die verhouding tussen Woord Gods en kerklike leer uit te druk nie. Die juiste verhouding tussen hulle kan alleen op die spoor gekom word as 'n mens rekening hou met die tydafstand wat daar bestaan tussen die Skrif as oorspronklike en normatiewe betuiging van Gods Woord en die kerklike belydenis as menslike reaksie daarop uit 'n later tyd. En die verhouding tussen hierdie twee is nou nie dié van identifikasie nie maar van interpretasie. 


\section{Konklusie}

Wat is nou teen die agtergrond van die leer oor die eienskappe van die kerk die ekumeniese implikasies van dit wat sopas gesê is oor die konfessionaliteit van die kerk? 'n Konklusie wat getrek kan word, is dat die belydeniskarakter van die kerk impliseer dat die eenheid van die kerk as instituut alleen op die vlak van die plaaslike kerk tot uitdrukking kom. Dit is die geval omdat die belydenis die wyse is waarop die Skrif sy gesag op 'n bepaalde tyd en plek laat geld. "Plaaslik" word hier dus as hermeneutiese kategorie hanteer 69 .

Dat die institusionele eenheid van die kerk alleen op plaaslike vlak tot uitdrukking kom, impliseer geen ontkenning van die eenheid van die universele kerk nie 70 . Dat dit die geval is, hang saam daarmee dat die eenheid van die kerk nie alleen 'n historiese nie, maar ook 'n eskatologiese werklikheid is. Hiermee word nie slegs bedoel dat die eenheid eenmaal in die voleinding finaal bereik sal word nie. 'n Nog meer fundamentele konnotasie wat dit het is om die intensief-kwalitatiewe katolisiteit van die kerk aan te dui71. Dit is 'n werklikheid wat voltrek word in die finaliteitskarakter van die belydenis. Dit geskied waar 'n mens die apostoliese getuienis aangaande Jesus hoor en waar die geloof in 'n belydenis konkrete gestalte aanneem. Daar kom die volheid van dit wat God aan die mens wil skenk tot stand. Daar kom die heerskappy van die wêreld ten einde. Daar is die ewige lewe teenwoordig midde in die tyd. Daar word die tydsruimte van die geskiedenis as't ware opgehef en word die gelowige gestel in die gelyktydigheid met Jesus Christus en so ook in die gelyktydigheid met die ganse geskiedenis van die kerk. En so staan die gelowige dan in die communio sanctorum, in die gemeenskap van die Heiliges wat alle tye en ruimtes omspan.

Die oorweging op grond waarvan die eenheid van die kerk aangedui is as die eenheid van die plaaslike kerk, is die feit dat die kerk creatura evangelii is en dat die kerk pas daar tot gestalte kom waar mense die Woord op 'n gemeenskaplike wyse kan verstaan. Hierdie gemeenskaplikheid word mede bepaal deur wat eerder beskryf is as 'n gemeenskaplike horison. Nou is dit wat hier met die term "horison" aangedui is nie 'n starre gegewe nie. Soos alle menslike werklikhede is dit in 'n dinamiese groei en ontwikkeling betrokke. Dit beteken prinsipieel en prakties dat die grense tussen kerke dus ook steeds aan die beweeg is en nie altyd presies op dieselfde plek lê nie.

Reeds eerder is daarop gewys dat die belydenis deur sowel voorlopigheid as finaliteit gekenmerk word. Vanweë sy voorlopigheid en die daarmee gepaardgaande gevaar dat die voorveronderstellinge van die menslike verstaansproses die Woord van God in beslag kan probeer neem in plaas daarvan om daardeur in beslag geneem te word, moet die belydenis telkens weer aan die Heilige Skrif getoets word. 'n Belangrike faset van hierdie toetsingsproses is dat die voorlopige visie van die belydenis teenoor die voorlopige visie van 'n ander belydenis geplaas word met die wedersydse oproep tot toetsing aan die Bybel.

'n Belangrike gesigspunt in verband met die funksionering van die belydenis is dat dit ' $n$ tweevoudige blikrigting het. Dit is in eerste instansie antwoordend tot die sprekende God gerig - voorlopig en finaal. Maar dit is ook getuigend en instemmingsoekend op die medemens gerig. Die finaliteit funksioneer steeds as oorsprong en doel van die belydenis. Daarom mag 'n kerk hom nie in selfgenoegsaamheid van ander kerke afskei nie en moet daar steeds na ekumeniese 
ooreenstemming en samewerking tussen hulle gestreef word. So 'n samewerking en ooreenstemming word egter nie nagestreef ter wille van die eenheid van die kerk nie. Die universele eenheid van die kerk is eskatologies gegee. Indien daar egter ooreenstemming en miskien selfs in bepaalde gevalle institusionele eenwording bereik word dan geskied dit op grond van die eenheid van die kerk en ter wille van die Christelike liefde wat daarop uit is om die gang van Gods Woord so goed as moontlik te dien.

Konkreet beteken dit dat institusionele eenheid tussen kerke nie kunsmatig, dit wil sê op grond van nie-konfessionele faktore, afgedwing mag word nie. Dit beteken eweneens dat kerke nie in 'n kunsmatige isolasie van mekaar mag lewe nie. 'n Kerk mag prinsipieel nie 'n geslote kerk wees nie. Die eenheid van die kerk tree dus eerstens as die institusionele eenheid van die plaaslike kerk na vore maar ook as dialogiese eenheid van plaaslike kerke.

\section{NOTAS}

1 Oor die agtergrond van hierdie spreuk, kyk R Slenczka, "Die Lehre trennt aber verbindet das Dienen?", $K u D$ vol 19 (1973), 125-149.

2 Vergelyk Nederduitse Gereformeerde Kerk, Handelinge van die Algemene Sinode 1990, 546-548. Kyk ook O Weber, Grundlagen der Dogmatik II, Neukirchen-Vluyn 1962, 609-625; H Küng, Die Kirche, Freiburg-Basel-Wien 41973, 313-425; J A Heyns, Die Kerk, Pretoria 1977, 114-150 asook E Schlink, Ökumenische Dogmatik, Göttingen 1983, 585-589.

$3 \quad$ Vergelyk Schlink, $a w, 586$.

4 Kyk K Bihlmeyer, Die Apostolischen Väter I, Tübingen 31970, 108, 124, 129 en 130. Vergelyk ook J Faber, Essoys in Reformed Doctrine, Neerlandia, 1990, 89.

5 H Denzinger et A Schönmetzer, Enchiridion symbolonum definitionum et declarationum de rebus fidei et morum. Freiburg im Breisgau 131976, 66.

6 Vergelyk G C Berkouwer, De Kerk I, Kampen 1970, 10.

$7 \quad$ Hans Küng beskryf die leer oor die eienskappe van die kerk onder die opskrif "Die Dimensionen der Kirche", kyk $a$ w, 313-425. Vir die presiese implikasies wat die gebruik van die term "dimensioneel" het, vergelyk $\mathbf{K}$ Heim, Glaube und Denken, Hamburg 1957, 50-80.

8 Vergelyk Berkouwer, De Kerk I, 158 asook W Pannenberg, Ethik und Ekklesiologie, Göttingen 1977, 222 en 234 en J A Heyns, "Eenheid in internasionale perspektief: isolasie deurbreek?!", C F A Borchardt (red), Die eenheid van die kerk van Chnistus, Pretoria 1987, 14.

$9 \quad$ Vergelyk Heyns, Die Kerk, 114.

$10 \quad$ Vergelyk Schlink, $a w, 589$. 
11 Kyk Berkouwer, $a w, 10$ en 13; Pannenberg, $a w, 240$ en Schlink, $a w, 588$.

12 Vergelyk Weber, $a w, 605$ en Berkouwer, $a w, 12$.

13 Kyk Heyns, Die Kerk, 109-110.

14 Oor die bepaling van die presiese aantal kenmerke of notae ecclesiae was daar in die Reformasietyd verskil van mening. Teenoor die Gereformeerdes het die Lutherane slegs die eerste twee van die hierbo vermelde kenmerke aanvaar, vergelyk die Confessio Augustana, artikel 7.

15 Berkouwer, $a w, 14$.

16 Vergelyk M Luther, Werke, W A 50, 629.

17 Heyns, Die Kerk, 111.

18 Vergelyk NGB, 29.

19 Vergelyk Heyns, Die Kerk, 109.

20 Kyk J van Genderen, "De kenmerken van de Kerk", W van 't Spijker et al, De Kerk. Wezen, weg en werk van de kerk naar reformatorische opvatting, Kampen 1990, 295.

21 Vergelyk Berkouwer, De Kerk I, 9.

22 Vergelyk Berkouwer. De Kerk I, 15 asook Heyns, Die Kerk, 114.

23 NGB 29.

$24 \quad$ HK 54.

$25 \quad$ Kyk J van Genderen, $a w, 296$.

26 Vergelyk NGB 29.

27 Dit tree heel duidelik in Ef 4:4-6 aan die lig.

281 Petrus 2:10.

291 Korintiërs 12:12.

301 Korintiërs 3:16-17. Vergelyk in hierdie verband W D Jonker, "Afsonderlike kerke vir afsonderlike bevolkingsgroepe?", Scriptura vol 17(1986), 1-14.

31 Vergelyk J A Heyns, Dogmatiek, Pretoria ${ }^{3} 1984$, 377-379.

32 Om maar slegs met een uit talle moontlike voorbeelde te volstaan, vergelyk A A van Ruler, "De betekenis van het institutaire (in de Kerk)", in: Idem, Theologisch Werk IV, Nijkerk 1972, 193-197. 
33 Die pluriformiteitsleer van Abraham Kuyper het in hierdie verband groot bekendheid verwerf. Vergelyk in hierdie verband W D Jonker, "Die pluriformiteitsleer van Abraham Kuyper", In die Skriflig vol 23/91(1989), 12 23.

$34 \quad$ Vergelyk Weber, $a w, 618$.

35 Ibid.

36 Vergelyk Johannes 15:3 en Efesiërs 5:26.

$37 \quad$ Kyk Weber, $a w, 618$.

38 Kyk by voetnoot 4 .

39 Bihlmeyer, $a w, 108$.

40 Vergelyk Faber, $a w, 86$.

41 Ibid.

42 HK 21:54.

43 Matteus 28:19.

44 HK 21:54.

45 Berkouwer, De Kerk I, 132-133.

46 Berkouwer, $a$ w, 136.

$47 \quad$ Kyk Pannenberg, $a$ w, 235.

$48 \quad$ Ibid

49 Vergelyk J Macquarrie, Christian unity and christian diversity, London 1975, 2.

$50 \quad$ Vergelyk Schlink, $a w, 589$.

$51 \quad$ Kyk Heyns, Dogmatiek, 383.

52 Oor die diskussie in verband met die presiese betekenis van die begrip apostolisiteit, vergelyk G C Berkouwer, De Kerk II. Kampen 1972, 1-38 en Pannenberg, $a w, 222-226$.

$53 \quad$ Kyk Berkouwer, De Kerk II, 88.

$54 \quad$ Vergelyk Berkouwer, De Kerk I, 228.

55 Ek gebruik die term "belydenis" hier dus nie in 'n bloot formele of neutrale sin nie maar vul dit onmiddellik met Christelike inhoud. Kyk in hierdie verband verder ook Heyns, Die Kerk, 179. 
56 Vir 'n bespreking van hierdie materiaal kyk my studie Dogma en Verstaanshorison, Amsterdam 1977, 49-94.

57 Vergelyk H Conzelmann, "Was glaubte die frühe Christenheit?", Theologie als Schrifiauslegung, München 1974, 106-119.

58 Vergelyk K Holl, "Zur Auslegung des 2. Artikels des sog apostolischen Glaubensbekenntnisses", Gesammelte Aufsätze zur Kirchengeschichte II, Tübingen 1928, 116ev.

59 Vergelyk E Schlink, "Die Struktur der dogmatischen Aussage als ökumenisches Problem", Der kommende Christus und die kirchlichen Traditionen, Göttingen 1961, 24-79.

60 Schlink, $a w, 35$

61 Vergelyk M Elze, "Häresie und Einheit der Kirche im 2. Jahrhundert", ZThK vol 71 (1974), 389-409.

62 Vergelyk G Ruhbach, "Aspekte der Bekenntnisbildung in der Kirchengeschichte", Idem et al, Bekenntnis in Bewegung. Göttingen 1969, 56.

63 Vir die ontwikkeling van hierdie opvatting vergelyk H W Rossouw, Klaarheid en interpretasie, Amsterdam 1963, 19-139.

64 Vergelyk Rossouw, $a w, 144-166$

65 Kyk G Ebeling, Die Geschichtlichkeit der Klrche und ihrer Verkündigung als theologisches Problem, Tübingen 1954.

66 Uiteraard tree hierdie insig na vore pas na die deurbraak van die historiese bewussyn in die Negentiende Eeu. En hierdie bewussyn op sy beurt kan beskou word as 'n uitvloeisel van die Aufklärung. In hierdie sin is dit begryplik as die "verdeeldheid" van die kerk aan die Aufklänung toegeskryf word, vergelyk J H van Wyk, "Geroep tot eenheid", $H$ du Toit en P Krüger (reds), Geroep tot eenheid. Gesprekke ter wille van die heling van die breuk tussen die GKSA en die NGK. Pretoria 1990, 12. Die probleme wat so ontstaan, kan egter nie opgelos word deur die Aufklänung en die gevolge daarvan weg te wens nie. Dit bly die opdrag van 'n behoudende teoloog om hulle met erns ter hand te neem.

67 Die identifiseerbare struktuur waarvan hier sprake is, mag nooit versekulariseer word tot die eiebelang van die eie groep wat sowel teenoor ander groepe as teenoor Christus verselfstandig word nie. Die identifiseerbare struktuur waarvan hier gepraat word, is 'n hermeneutiese kategorie wat ' $n$ rol speel by die verstaan van die evangelie op sy weg deur die geskiedenis heen. Dit hou ook verband daarmee dat die geloof 'n konkrete eksistensiële werklikheid is en nie maar net 'n stel abstrakte leerstellings of ' $n$ abstrakte ideaal nie. Oor die problematiek van die eie identiteit in die kerk vergelyk Berkouwer, De Kerk I,90. 
68 Vergelyk W Joest, "Endgültigkeit und Unabgeschlossenheit des Dogmas", $T L Z$ vol 79 (1954), $435-440$ asook H W Rossouw, "Doksologie, Ortodoksie en Ekumene", NGTT vol 14(1972), 207 en 208.

69 Om hierdie gesigspunt teen moontlike misverstande af te grens, kan beklemtoon word dat dit in die konstellasie van verstaansvoorveronderstellinge wat die kategorie plaaslikheid konstitueer gaan om "n histories bepaalde voorsienigheidsordening en nie om 'n vermeende skeppingsordening nie" (Heyns, Die Kerk, 128). Vergelyk vir 'n dergelike gedagtegang ook Weber, a $w, 619$. Daarom sal dit later ook blyk dat die kategorie plaaslikheid ook nie staties is nie.

70 Vir die agtergrond van hierdie gedagtegang vergelyk $\mathbf{G}$ Ebeling, Wort und Glaube I. Tübingen 31967, 161-191 asook Idem, Wont Gottes und Tradition, Göttingen 21966, 9-27. Kyk ook my artikel "Homologie en Hermeneutiek", $H T S$ vol 44(1988), 540-559.

71 Vergelyk Weber, $a w, 619$. 